\title{
The temptation of Realpolitik and vox populi in the ecclesiology of the Emerging Apostolic Churches with special reference to the fivefold ministry
}

\author{
K Thomas Resane \& J Buitendag \\ Department of Dogmatics and Christian Ethics \\ University of Pretoria ${ }^{1}$
}

\begin{abstract}
The Emerging Apostolic Churches do not have a uniform church polity since the power of governance is claimed to be with the fivefold ministers, while at the same time embracing either the Episcopal, Presbyterial, or Congregational church governments. The fivefold ministry is a generally accepted term that refers to the five ministries given by Christ to the Church to stand in unique spiritual offices, as found in Ephesians 4:11. This article tries to answer the question: "Are the Emerging Apostolic Churches ecclesiologically correct by centring the authority of governance in the fivefold ministers and the popular voices of the followers?" At the same time it is endeavored to argue that due to Biblical and theological grounds the fivefold ministry is untenable to church polity hence Realpolitik and vox populi dominating the ecclesiastical life and polity of the Emerging Apostolic Churches. The aim is to demonstrate that these two concepts (Realpolitik and vox populi) play a significant part in shaping the church polity and structures of this ecclesiastical phenomenon.
\end{abstract}

\section{INTRODUCTION}

The aim of this article is to critique the theological understanding of the Emerging Apostolic Churches regarding the fivefold ministries of Ephesians 4:11, and to explore the forces of Realpolitik and vox populi in shaping the church polity of these churches. These churches can be broadly defined as

\footnotetext{
${ }^{1}$ Article based on research for the PhD degree conferred on 4 September 2008 at the University of Pretoria, in the Department of Dogmatics and Christian Ethics, under the supervision of Prof Dr J Buitendag.
} 


\section{The temptation of Realpolitik and vox populi}

non-historical charismatic churches that accept the fivefold ministry as the foundational government structure of the church. They have lately been variably defined in literature, but I have coined the name, Emerging Apostolic Churches or Movement. The views expressed in this article are the outcomes of personal engagements and interactions with various leaders of this ecclesiastical phenomenon. The literature study is engaged as a way of backup for the arguments. The explosion of this movement worldwide calls for some theological assessment regarding its dogma, polity and ethics. Since this is an ecclesiastical phenomenon, it is legitimate to scrutinise and locate its polity within Systematic Theology as opposed to any other theological discipline such as Church History or the New Testament Studies.

The historical roots of the fivefold ministry can be traced to the Latter Rain Movement, a branch of the early twentieth century Pentecostalism of the 1940s. It is the belief that the apostles and prophets are being restored to the church, making the fivefold gifts of Christ in Ephesians 4:11 fully operational. All the historical Charismatic tenets such as the Shepherding Movement, the Positive Confession Movement, the Third Wave, the New Apostolic Reformation, and the Emerging Apostolic Churches of the modern day had embraced the fivefold ministry as fundamental to their church polity. The movement insists that for the church to experience growth results, it must recapture the New Testament pattern. This New Testament pattern, as alluded by Moriarty (1992:95-96) "must be restored to equip the saints for the work of ministry. The church will not be as effective in the dominion process unless the fivefold ministry expounded in Ephesians 4:11 is restored and recognized by the church at large ... they are essential, not optional".

The Emerging Apostolic Churches describe apostles as the leaders who are totally responsible for the church government. Many feel that traditional church government structures ought to be abolished in exchange for fivefold ministry teams. These teams appoint ministry elders and leaders. The apostle is the visionary and the father figure. On the other hand, prophets and prophetesses are for direction, confirmation and edification for the church, while the evangelists not only bring souls to Christ, but integrate them into the church and also encourage others in how to win souls. Pastors are expected to build relationships with the people and establish visitation, while teachers are responsible to teach the Bible, explain the apostle's doctrines and train and motivate the people to walk in righteousness.

The modern day voices regarding the fivefold ministry echo from leaders such as Paulk, John Gimenez, David Cannistraci, Ken Sumrall, Gary Greenwald, Norvel Hayes, Bill Hamon, Terry Virgo, and of notably and lately, Peter Wagner. These are of the persuasion that there are the foundational fractures in the body of Christ and that these fractures can be remedied by the 
restoration of apostolic and prophetic leadership ministries. These ministries enhance those of evangelists, teachers, and pastors. All five offices mentioned in Ephesians 4:11 are needed in the church for the complete equipping of the people of God and a proper building of the church. One of the fivefold ministry promoters, Bishop Stone (1999:5) says "this fivefold ministry ... should be evident in the life of any church that is fulfilling God's purpose". In summarising the utterances and the writings of these leaders, conclusion can be drawn that the fivefold teachers are convinced that the apostles or the apostolic teams exercise authority in equipping the church and advancing the kingdom of God. Their mandate is to:

- establish new churches and oversee the ongoing development of existing churches;

- appraise a local church's condition;

- point out the local church's shortcomings and apply some corrective measures;

- rebuke sins of coldness, doctrinal instability, and faulty practices;

- protect the church against dangers of legalism, false doctrine, and many cultic invasions that may obstruct the church's journey towards the likeness of Christ;

- establish proper church structure.

These apostolic leaders believe that God is preparing a company of modern prophets. Bill Hamon in particular is vocal and persuasive on the prophetic movement. In his circles one finds the likes of Cindy Jacobs, Frank Demazio, and Ernest Gentile. In the foreword of Bill Hamon's (1999) book, Prophets and prophetic movement, Dr Gary Greenwald declares that, "The supernatural Prophetic Movement is God's standard that $\mathrm{He}$ is raising up to expose and overcome the flood of demonic activity in witchcraft, satanic seduction, occultic manipulation and the New Age Movement ...There has never been a more timely need of the restoration of God's prophets than at this very hour." The fivefold teachers believe that the prophets are raised up for the purpose of:

- equipping the church in the spirit and power of Elijah to prepare the way for Christ's second coming;

- receiving from Christ the proper revelation and application of the Bible;

- remedying many of the problems that exist in the church today;

- causing the church leaders to re-examine their churches' activities in light of the new truths the prophets bring. 


\section{The temptation of Realpolitik and vox populi}

It is important to note that the Emerging Apostolic Churches are insistent on the fact that it is important for young prophets to be trained and discipled by older and more mature prophets. Moriarty (1992:98) expresses this thought that "revelatory instruction on how to hear the voice of God and how to adjust to and handle a 'new anointing' is vital to the young prophet's ministry". It is generally accepted that the Spirit's dynamis is tangible in wisdom, hope, courage, endurance, joy, and charismata. The charismata are felt to be the dynamis pneumatos - the strength of the Spirit. To borrow Bultmann's (1965:56) expressive notion: in the charismata the strength of the Spirit is given expression.

The Emerging Apostolic Churches have a tendency of developing deeply trusting and submissive relationships to the authority figures who display the apostolic authority and charisma. They exhibit a strong need for external guidance from some trusted authority, a figure more powerful than themselves who assures them of security and direction in their ecclesiastical ethics and code of conduct, including the theological affirmations. There is an "overinvestment" of feelings in the leaders to the point of idealizing them as nearly perfect parents. These leaders are recognised as apostles by virtue of easily discernible personal charismata. Quebedeaux (1983:98) confirms this that:

these persons would rise to positions of leadership without regard to bureaucratic training requirements or upward mobility through the ranks ... Many such leaders are, in fact, endowed with a degree of personal charisma, which helps them, but it is really their standing (ecclesiastical, intellectual, or social) that enhanced the emergence of these clergy and laypeople in organizational leadership circles.

The apostolic leaders command the general respect and admiration of local church leaders who lead and exercise authority over their followers in the context of the various ecclesiastical practices to which their local churches adhere. Despite the inherent dispersion of charisma and the presence of local authority figures, the emerging apostolic movement has a widely recognised national and international, charismatic and organisational, leaders who preach, teach, inspire, mentor, and guide the direction of the movement and a measure of cohesiveness to a decentralised, segmentary, and weblike structure. In this decentralised movement, apostolic leadership dominates. The apostolic leaders have the authority of persuasive influence over others. They inspire faith and loyalty, since they are seen as pneumatikoi-special bearers of the Spirit. 
In the Emerging Apostolic Churches, ecclesiastical activities and manifestations have been democratised. Although the ecclesiastical expressions are apostolic leader oriented or leader dominated, church ministry itself is conceived as "body ministry" - the whole church of Christ witnessing. The power of leadership is balanced against the role of the community members. There are apostolic leaders who hold and wield absolute authority. Submission to authority is expected to be a mutual submission. It has been observed that an apostolic leader might demand submission to his authority as the chief discerner of the Spirit, and teacher of theology, without allowing much theological negotiation or interactions among the other community leaders.

\section{THE THEOLOGICAL ASSESSMENT OF EMERGING APOSTOLIC POLITY}

The fact of the matter is that the Emerging Apostolic Churches are diverse in their polity. The unifying factor in regard to their polity is the fivefold ministries. The ecclesiological understanding of polity serves as a precursor to the understanding of the fivefold ministries. It is generally accepted in ecclesiology that ecclesiastical polity is the operational and governance structure of a church or Christian denomination. It also denotes the ministerial structure of the church and the authority relationships between churches. Polity is closely related to ecclesiology - the study of doctrine and theology relating to church organization.

Ecclesiastical polity is used in several closely related senses. Most commonly it refers to the field of church governance in the abstract, but it also can refer to the governance of a particular Christian body. In this sense it is used as a term in civil law. Polity is sometimes used as a reference for the church governance structure itself. The key words of church polity are governance and organization. It is a way in which a local church or a group of churches organize and administrate themselves. It is in part the organization of a group of believers in definitive, prescribed patterns. Ecclesiastic organization ideally brings symmetry, harmony, and discipline within the membership of the church. It is the organization that defines the corporate relationship of Christians to people outside the ecclesiastical circles.

The doctrinal differences are minor as they are always peripheral to faith and the deity of Jesus Christ, or even the credibility of the canon. Church traditions had been uniquely separated by their polity. This is the pattern of governance. It is generally accepted that the Episcopalians govern themselves by bishops, Presbyterians by elders, and Congregationalists by local members. Governance may be at least as important as creeds in 


\section{The temptation of Realpolitik and vox populi}

understanding denominations. Long (2001:2) assesses it correctly that, "Polity provides institutional cohesion to many groups."

The Emerging Apostolic Churches are insistent on the fact that the church is to be governed by the fivefold ministers. One of their teachers, Ron Myer (2006:55-117) elaborates that apostles govern, prophets guide, evangelists gather, pastors guard, while teachers ground. One of the famous teachers and proponents of the fivefold ministry is Bill Hamon. He emphasises that "all fivefold ministers are called to govern, guide, gather, ground and guard God's people" (Hamon 2002:150). These teachers emphasise the fact that these ministries are governmental ministries. They involve responsibility, accountability, and authority.

Theologically, it is difficult to assess the fivefold ministry polity without intra-textual examination. At this stage the text is Ephesians 4:11. In this text, the author selects only five gifted roles given by Christ to equip the saints for the work of the ministry. It is clear that the purpose for the fivefold ministry was never designed to govern, but to empower the church that was already established. To treat Ephesians 4:11 in isolation without connecting it with the subsequent verses, especially verses $12-13$ is to do the hermeneutical injustice to the text. These two verses elaborate the purpose of these five gifts listed in verse 11. In following the Authorised King James Version, the purpose of these fivefold ministers is threefold: for the perfecting of the saints, for the work of the ministry, for the edifying of the body of Christ. The connectives "pros" and "eis", both translated "for", make the reference to both ultimate and immediate purpose. Martin Lloyd-Jones (1984:198) agrees that, "The ultimate purpose of all these offices and divisions of labour in the Church is the perfecting of the saints, and the way in which the saints are to be perfected is through the gift of the ministry, the function of which is to edify the body of Christ. There is an ultimate objective, and there are more immediate objectives."

The danger of following this path is to conclude that the fivefold ministers are endowed with extra or special abilities or powers. The Ephesians were a settled charismatic community that had government in place already - long before the letter was written (Ac 20:13-38) to them. The purpose of the passage was never to build a fivefold edifice or to endow five offices with rare powers for the sake of the restoration of the church before the Parousia. The gifts mentioned are not charismata, but doma. They are given to empower what is already in existence.

The other theological assessment of this movement is the tendency to privatise God's revelation. The doctrine of the priesthood of all believers, which is one of the distinctives of evangelical faith, is at stake with this 
approach. It seems all powers, revelation, knowledge etc is centred on the fivefold ministers. It is shocking to read Earl Paulk's citation (1987:10) alluding that no person apart from those in the fivefold ministry has the right to interpret the Bible. This can lead to the tragic reconstruction of the Church before the Reformation. This is like reverting to the Middle Ages with this elevation of fivefold hierarchy. The Berean model in Acts 17:10-11 should be a focus instead. Moriarty (1992:195) gives a clear assessment that, "The fivefold ministry promoted by the new charismatics is an unbiblical authoritarian model that obliterates the responsibility all believers have in testing and examining teaching to see if it is in accord with biblical revelation." This model places ordinary Christians at the mercy of authoritarian leaders and their fanciful interpretations.

\subsection{The hermeneutical analysis regarding the fivefold ministry}

The first step in hermeneutics is to establish the correct wording of the passage. This is because, as Marshall (1997:11) points out: "Different editions of the Greek New Testament vary in their wording according to their editors' estimate of the relative reliability of the early manuscripts." This article limits itself to textual criticism, since the matter is a technical one and there is already abundance of materials on the subject. The textual criticism expounds what the text or passage itself says, rather than what the interpreter wishes to draw from it in order to give expression to his own thoughts or ideas. The method compels the interpreter not only to break it up into its headings of the discourse, but is compelled also to relate the passage to its context in order to arrive at its accurate meaning.

Ephesians 4:11 has been in a spotlight from the beginning of the twentieth century when the Pentecostal Movement was born. In following the text criticism, it is important to note that verse 11 cannot be treated in isolation without taking the broader context of the book especially the era from which it emerged. In text criticism, as McQuilkin (1983:123) asserts, "the primary source for understanding the setting of a passage is its context. The most important element in a word study is its use in a particular context. Again, ambiguities in grammatical structure are often resolved through reference to the context". The fundamental guideline is examining the immediate context, which embraces the passage as a whole, the book as a whole, and all historical contributors to the existence of the text. The following brief exegesis of this verse will enable one to move on with the theological assertion regarding the fivefold ministry. 
"It was he who gave" (kai autos edōken). The reference is to Christ as per context from verse 7 . The passage from verse 7 has no reference to the Holy Spirit, but like most of the epistle, very Christological in approach. This means that Christ is the one who dispenses these gifts (domata). Barth (1974:435) confirms this that "By his gift the exalted Christ establishes an order and gives the church a constitution. Gift and institution, or charisma and office, are not mutually exclusive alternatives, they are combined and inseparable." These domata are immediately given from above. Christ gives the church the ministries she needs. The exalted Christ dispenses the gifts or ministers to the church.

The five roles or ministries listed had been disputed. Some commentators restrict themselves to four by alluding to the fact that pastors and teachers are one and the same gift. The apostle, prophet, and teachers appear in other texts that refer to charismata, especially 1 Corinthians 12:28, but poimena (shepherds) and euangelistas (evangelists) do not. The evangelist in the epistles is only mentioned here and in 2 Timothy 4:5.

The article, tous men, tous de is repeated four times before the doma previously listed, but is missing before didaskalos (teachers). It is to be noted that the conjunction kai found between "shepherds" and "teachers" does not always mean "and", it may also mean "that is" or "particularly". Barth (1974:438) tries to unravel this text riddle by pointing out that "since in Eph $4: 11 \mathrm{~d}$ the conjunction is not followed by the pronominal article, it is probable that it designates 'shepherds' and 'teachers' as one common group which complements the other three groups of 'the apostles', 'the prophets', and 'the evangelists'". There are few observations to be made regarding this verse:

- Christ's gifts in this text are not spiritual gifts (charismata), but doma something that is divinely bestowed for sustenance. The character of the gift is stressed more than its beneficent nature (Vine Dictionary 1952:477).

- The gift of Christ is unfolded in diverse ministries. Christ Himself gives the church a diversity of services. The fundamental theme of the entire section is the unity of the church. This is the unity in variety, a unity in diversity. This necessitates the organisation of the church for Christ Himself is He who gives some to be apostles, some to be prophets ... et cetera. People do not call themselves to these ministries. 
- The gift of Christ to the church consists of people. The gifts are not impersonal. The church of Christ consists of members, each having a function under the Head, Christ Himself (Eph 4:7).

- The gifts of Christ are all the speaking gifts. Their services are fulfilled by speaking. They are all the ministers of the Word.

- All work in unity for the strengthening of the body of Christ. This is the original intentions of the writer of the text.

\subsection{The theological focus of Ephesians 4:11}

The theological focus of Ephesians 4:11 is Christ and His generous distribution of gifts to His church. Christology and ecclesiology are at the centre of this verse, when taken into the context of the whole epistle. The focus of the whole epistle is the Dignity of the Church as the Body of Christ the Head (Robertson 1931:515). Theological reflections of this verse brings to the fore

- The supremacy of Christ. "It is he who gave ..." is the statement that reveals the power of Christ to do things extra ordinary. The object here is to demonstrate the power of Christ in providing the means for the construction of the church. In the real sense, Christ is head over entire universe, and there is no greater power than His. This is confirmed by en Christos, the term prominent in the Pauline corpus is found in Ephesians thirty-six times.

- The empowerment of ecclesia. One theme running through the epistle is church. The epistle was not directed to novices in the Christian faith, but to those who, having achieved some maturity in spiritual experience, wished to go on to fuller knowledge and life (Tenney 1978:318). The church is a single functioning body, and is equipped with standards of its own since it is engaged in a spiritual conflict. Its goal is unity in the faith, the knowledge of the Son of God, and maturity, which is the measure of the fullness of Christ (4:13).

All those in Christ are called, trained and given all the necessary arms. They do not form a special class, rank, or caste in the body of Christ. Their task is to minister to the church for Christ's sake. Every one of them is a servus servorum Dei - the pastor of God's flock, who understands himself as a minister to ministers. 


\title{
2.3 The ecclesiastical tradition of church leadership
}

It has always been a church practice to be hierarchical or monarchical in its government, rarely democratic in principle. Martin Lloyd Jones (1984:177), in referring to the domata of Ephesians 4:11 warn sternly,

\begin{abstract}
Nothing is so far removed from the Apostle's picture of the Church as institutionalism and ecclesiasticism. These 'isms' are not to be found anywhere in the New Testament. Institutionalism is a denial of the picture of the Church as the body of Christ, and of Christ alone as the Head, and of the Holy Spirit making and preserving this blessed unity. Ecclesiasticism is as much a denial of the scriptural teaching as is the chaos that is seen in other circles at the present hour where men set themselves up and recognise no authority whatsoever.
\end{abstract}

Institutionalism takes roots whenever and wherever power is vested on an individual or a group of individuals. Institutionalism practises power over the subjects. In this matter the Emerging Apostolic Churches concentrate power on the fivefold ministers. They are the sole leaders of the church and their manoeuvring on spiritual matters is not supposed to be questioned. Individualism reigns supreme. On the other hand, ecclesiasticism creates a team of "holy club". The church becomes a closed society where only the chosen few are welcome. The power is applied and wielded by applying the rules, procedures, and policies instead of listening to God's Word and the leading of His Spirit. The constitution becomes the supreme law instead of the Bible.

\subsection{The present scenario - Theological assessment by proponents of fivefold ministry}

The emerging Apostolic Churches are of the view that the church is to be governed by the fivefold ministers as stipulated in Ephesians 4:11. There is a belief that the church is in trouble because she refuses to recognise the offices of apostle and prophet as valid for today. The cornerstone of this belief is Ephesians 2:20, built on the foundation of the apostles and prophets, with Christ Jesus himself as the chief cornerstone. The new foundations are laid and are established in an experiential way by modern apostles and prophets who are part of this foundation. A church without apostles and prophets has faulty foundation. These apostles and prophets hold a unique role of teaching that includes the delivery of new doctrinal revelations. The fivefold ministers believe the following about these five ministries.

An apostle is someone sent out with divine authorization. According to Peter Wagner (1999:104-105), "apostle is a spiritual gift ... The gift of apostle 
is the special ability that God gives to certain members of the Body of Christ to assume and exercise general leadership over a number of churches with an extraordinary authority in spiritual matters that is spontaneously recognized and appreciated by those churches". This definition is found in two books (Changing Church, 2004 and Apostles Today, 2006) of the same author to demonstrate this movement's dogmatic persuasion regarding the identity of the apostle. The inevitable term accompanying an apostle is "authority." This is also confirmed by David Cannistraci (1996:29) that an apostle is "one who is called and sent by Christ to have the spiritual authority, character, gifts, and abilities to successfully reach and establish people in Kingdom truth and order, especially through founding and overseeing local churches." The apostles are like ambassadors who represent a country - a notion substantiated by Bill Hamon (1999:124) that "the basic root meaning of apostle is one sent as representative of another, with the power and authority of the representative coming from the one who sent him". The movement elevates apostles' function as that of exemplifying power. This is the power to perform signs, miracles, and wonders, which is the power to destroy the strongholds of darkness and hell. The apostle governs over the congregations for the purpose of establishing government of the kingdom of God. How one builds Christ's church is crucial. It is not a personal property or possession, but Christ's church, therefore, "the apostle's responsibility is to build a government based not on himself - nor on any human philosophy, thought, or idea - but on the Word of God" (Stone 1999:8).

Some fivefold scholars believe in the apostolic ministry in the church today, but not as a title or office or position of power. They insist that the apostolic office foundational to the New Testament church may have ceased, but the gift of apostle remains as a continuing endowment on the body of Christ. Peter Wagner (1999:105-106) disputes the equivalence of apostle with the missionary, while Rice Broocks (2002:176) asserts that at a basic, semantic level, to be apostolic means to simply function as a missionary in planting churches. This demonstrates how within this ecclesiastical tradition can there be diverse and varying views on apostles.

However, the fundamental understanding of the apostles in the New Testament, as described by Ray Robert Noll (1993:221), is that they "were primary officers of the Church who needed no legitimation, and that they were the first or among the first to preach (the name of) the Son of God ..... In other words, the apostles were the heralds of the fundamental Christian kerygma.

The fivefold ministers are always at loggerheads in identifying the prophet. Ron Myer (2006:70) summarises the general identity of the prophet 


\section{The temptation of Realpolitik and vox populi}

that the broad spectrum of this ecclesiastical phenomenon accepts the fact that a prophet is

someone who sees what others do not, who hears what others cannot, who speaks what others will not. A prophet is someone who has the ability to consistently speak forth God's heart to His people. The prophet sees the real issues and priorities. He calls us to action and points the way. A prophet is one who speaks forth God's heart and mind maturely and who has a proven record of accuracy.

A prophet is God's mouth-piece, speaking prophetic things in advance. The prophet's function involves purpose and destiny. The prophetic ministry is exhortation or encouragement. The goal is to build up and strengthen. Bill Hamon (1999:25-30) summarises the prophet's ministry as that of preaching restoration, which is one of the central doctrines of the Emerging Apostolic Churches. Bishop J L Payne (2004:112-117), a vibrant promoter of the fivefold ministry sketches the important character traits about the restoration period prophet:

- A prophet's ministry imparts spiritual directions to the people of God. The character of the true prophet is revealed when his prophecy and predictions come to pass.

- A true prophet's ministry will always be in harmony with the Word of God (1 Cor 14:29).

- A true prophet will always build and help establish the work of God. He compliments the apostle's ministry.

- A true prophet witness is established in the mouth of two or three witnesses.

- A true prophet prophesies in the revelations and the gifts of the Spirit.

- True prophet's prophecies are as God gives to him and God warns of penalty from Him when that prophet does otherwise.

- Prophet's ministries may differ but unity prevails.

- New Testament prophets are involved in revelation of information into people's lives, of times, their problems, and sins.

- A prophet is an exhorter. He urges the people with excitement to build.

Like in the case of apostle, the fivefold ministers believe that a prophet is a gift to the church. This gift is especially given to the church, as Cindy Jacobs (Green 2005:47) says: "to expose, shift, and bring transition to nations". Prophets speak to nations to encourage God's people to respond to the word 
of the Lord. They have the right to prophesy direction, correction, guidance and new revelation to an individual, community (church) or the nation. The prophetic word is transformational when God's people believe it. Jacobs' proposal seems to clash with that of Wagner, who sees the fivefold ministers as the governors of the church more than gifts. Jacobs seems to be emphasising the "gift" aspect as opposed to leadership role.

The Ephesians 4 evangelist is an equipper of others, not just the doer of evangelism. The basic ministry of the evangelist is deliverance and leading people to salvation in Christ. Kerygma and soteriology are the twin doctrines of the evangelist. The emphasis is on kerygmatic expression of soteriological acts of Christ. The evangelist's mandate is kyruxon ton logon (proclaim the word), as found in 2 Timothy 4:2. The evangelist reaches the lost outside the church, therefore a career of good news. Like Philip of Acts 8, evangelists plant the churches.

The pastor is the shepherd of God's flock. He is the senior spiritual authority in a local church. His function is to feed and provide. He is expected to love, cherish, honour, and protects the church. The pastor prepares God's people for the coming of Christ. His function is therapeutic and eschatological - leading God's people to the fulfilment of His promises.

The teacher is there to lead the saints to maturity, to build them up and to bring balance into the life of the church. He is gifted to explain, illuminate, and persuade. The teacher is expected to maintain accuracy in handling God's word. More like a pastor, the teacher's function is ecclesiastical by making sure that the church is fully established on the right foundations.

The theological assessment of the fivefold ministry approach to ecclesiastical polity impresses upon one's mind that there is a disregard for what Pannenberg (2001:198-214) calls "the multiplicity of biblical ideas of revelation". This notion is based on one passage out of one epistle of the New Testament. The evangelical hermeneutics had always safeguarded itself against tangency of constructing dogma out of one verse or passage of the canon.

\section{IMPORTANCE AND MEANING OF THE TERMS: REALPOLITIK AND VOX POPULI}

Realpolitik is a term chiefly applied to foreign policy and indicating an alert opportunism. The word was coined by the political writer A $L$ von Rochau (1810-1873) in the title and text of his Grundsätze (2 vols, 1853-69). Realpolitik was held in high esteem in Germany in the Bismarckian, Wilhelmine, and National Socialist organisation. 


\section{The temptation of Realpolitik and vox populi}

It is a term used to describe politics based on strictly practical rather than ideological notions and practiced without what would be considered sentimental illusions. Realpolitik is usually used pejoratively as a term to imply politics imposed by means of physical violence, political extortion or economic suppression or to imply completely amoral politics aimed solely to achieve the goals by any means. In theological application, it is used for exercising power over spiritual lives of the people. In other words it is the power abuse. Van Gemeren (1990:26) captures it better in the religious context that "Realpolitik, or power politics, is a pragmatic application of any technique by which an individual or a group can maintain or enhance life. It is manipulative, works at the expense of others, and undermines the essential nature of revelation." It therefore, embraces the slogan that the end justifies the means. Anything is fair in achieving the goal.

Furthermore, in religious circles, Realpolitik operates from the assumption that the religious structures are basically good and that people can improve their lives and society by preserving and improving the existing structures - never replacing them with something new. The founder of the ideology is revered and that his word must be followed unreservedly. This explains why we have systems such as Socialism, Marxism, Communism etc founded by some historical figures whose ideologies are sacrosanct even after many centuries. There are also theological ideologies that Christendom or certain branches thereof, find difficult to replace or abandon. For an example fundamentalism, evangelicalism, Protestantism, Pentecostalism and many more that we can think of.

Realpolitk has nothing much in common with authority. It has weight on power. In the Emerging Apostolic Churches addressed in this article, it is the so-called potestas sacra - holy power, through which the structure and the life of the church are controlled. This is sometimes coded as influence, where charismatic leaders exert influence on followers, especially in the spheres of their experiences, feelings, thinking, and conduct in general. Realpolitik in spiritual realms divides people into rulers and subjects, the more and the less powerful.

On the other hand there is vox populi - the voices of the masses or populism. It is not limited only to the popular views, but it also expresses itself in traditions. Many church leaders, in particular of the group under the spotlight in this article (Emerging Apostolic Churches) search for freedom, prosperity, and happiness by establishing alliance with others of the same mindset to form the basis of laws, ecclesiastical interactions, cultic expressions and traditions. At the end vox populi emerges to reward those who support the common ideals but punishes anyone who challenges them. 
Vox populi shuns the demands of revelation by softening the radical nature of faith in favour of popular expectations. The Old Testament prophets, the Pharisees, and the Sadducees were bound by vox populi.

\section{THE APPLICATION OF REALPOLITIK AND VOX POPULI IN THE CHURCH POLITY OF THE EMERGING APOSTOLIC CHURCHES}

The Realpolitik is displayed by the excessive authority placed on and played by the apostolic figures of the Emerging Apostolic Churches. The theological emphasis of this movement is on apostles and prophets. It is believed that apostles are the founding fathers of the church and their task is to lay the apostolic foundations that cannot be challenged. These leaders, on many occasions display absolute power. They control their flocks and do not allow followers to grow beyond themselves. The Abundant Life Church in Nigeria is spreading like a wild fire in many parts of the world. The churches on Sundays listen to the apostle either on tape, CD or a video cassette. The local pastors are not allowed to prepare their own messages. This is controlling the minds of people that all the followers must acknowledge only one leader. There is an apostle in South Africa who runs one church in USA and one in Johannesburg. He flies between two churches on bi-weekly basis. The question that arises with this system is how pastoral is this leader. Is there any emotional connection with the flock? The apostles and prophets wield excessive power in the Emerging Apostolic Churches. These two "offices" overshadow the other three (evangelist, pastor, and teacher). Very little is said or written about the other three ministries of evangelist, pastor and teacher. The lack of prominence on pastors raises questions of their validity in the fivefold polity.

This leaves no doubt that hierarchicalism plays a major role in this church tradition, though it is denied and hidden behind the promotion of priesthood of all believers. All the literature studies of this church practice attest to the fact that the apostle is the main figure or character of the church. The prophets occupy the next in rank and the last three (evangelist, pastor, and teacher) receive a sparse treatment. The danger here is that doma here is arranged according to a scale of priority. This leaves the charismatic nature of the church at stake since the routinisation of the charismata comes to the fore to play a front role. The hierarchic principle is asserted against charismatic equality.

The apostles are mainly emulating the monarch rulers. Apart from the way they dress and groom, their utterances are expected to be received as infallible. The term justifying this acceptance is "anointing". They are the 


\title{
The temptation of Realpolitik and vox populi
}

anointed servants of the Lord and must be given the king's welcome reception wherever they go. Peter Wagner (1999:109) acknowledges that apostles are alive and kicking in this generation. According to Wagner, these apostles "manifest extraordinary spiritual leadership, and are anointed with the power of the Holy Spirit to confront the powers of Satan, by confirming the gospel by signs and miracles and establishing churches according to the New Testament pattern and doctrine of the Apostles". Wagner and Hamon, in all their works on apostles and prophets try to convince us that apostles are spiritual people. There are some that are definitely spiritual, but we have seen that many are not there as servants but as officers. The close examination of the fivefold exponents reveal that the fivefold ministers are not just gifts to the church but officers also.

Apostles of the Emerging Apostolic Churches claim authority over their followers' lives. Richard Dobbins (Green 2005:138-139) speaks of thugs in the pulpit. In referring to the pastoral role in church structure, he warns that

\begin{abstract}
abusive pastors also carefully select the leaders for their congregations. They choose men and women who are willing to give total and unquestioned allegiance to the pastor in return for position of prominence and power in the church. The leaders become the abusive pastor's agents for controlling and manipulating the congregation. The degrees of pastoral abuse may be viewed on a continuum ranging from financial abuse to sexual abuse with diminished personhood in between.
\end{abstract}

This is Realpolitik. As mentioned above they seem to be the people with revelation and this is confined to them alone. It is to be theologically asserted here that Christians are not expected to search for God through religious manipulations, because the Lord has given them His revelation. This is in agreement with Pannenberg (2001:225) that "[i]n revealing himself, God reveals himself. God and God alone is the object that the divine revelation reveals, God and nothing else." The apokalupsis of Christ is the revelation of who God is. This God is the great King, the Creator of everything, the Sovereign King over all nations. He guides and protects His people who submit to His sovereignty, and He gives wisdom to all who seek Him diligently. The apostolic leaders tend to take this position of power by controlling people's movements, spiritual journeys, and life in general. However, as Van Gemeren (1990:26), says: "He rewards all who abandon the path of Realpolitik and the vox populi for the 'paths of righteousness' (Psalm 23:3)." The Lord condemns anyone who relies on self or human structures (Realpolitik), and human system of value (vox populi). 
It is observed that the Emerging Apostolic Churches have a tendency of mixing religious ways with selective interpretation of God's revelation. The good example is the treatment given to Ephesians 2:20 and 4:11 as stated above. This does not do justice to the hermeneutical principle of tota Scriptura whereby the text is to be taken into the context of the whole plan of redemption, and how it fits in with the other parts of the canon. The exegetical methods of texts are questionable. Peter Wagner endeavours to justify this approach by dedicating two chapters in one of his books, "Changing church" (2004). He calls these chapters "From theological education to equipping ministers" and "From a heavy doctrinal load to a lighter doctrinal load." His point of departure is that training is replaced with equipping, and seminary is replaced by ordination. This undoubtedly releases half-baked people into the ministry, hence lots of theologically questionable dogmas and praxis within the movement.

Many apostolic leaders were in the past decade or so, unknown and unpopular. Their exploding churches around the world are not a guarantee that they are theologically correct in handling the word of truth. Their charisma of attracting multitudes cannot be regarded as authentic spirituality. The writer Anthony Trollope (2006:111) once said, "Marvellous is the power which can be exercised, almost unconsciously, over a company, or an individual, or even upon a crowd by one person gifted with good temper, good digestion, good intellect, and good looks." What he describes is charisma - the ability to attract others. But the real effects of charisma are only temporary. It can sometimes get you in the door, but it can never sustain you once you're there. For lasting influence, one has to look deeper. Character must be under the scrutiny. There is a popular saying that there is no substitute for character. One can buy brains, but cannot buy character. Character sets one apart. Truthfully, character often sets one apart from great many leaders today (vox populi). It is true that charisma can make a person stand out for a moment, but character sets him apart for a lifetime. Leadership functions only on the basis of trust. Charisma can draw people to the apostolic leader. With character, one builds trust with others each time he chooses integrity over image, truth over convenience, or honour over personal gain. Charisma, by its nature, doesn't last long or extend very far. It's like a flash of gunpowder. It produces a quick blinding light, but then it's gone. The people who witness it are impressed for the moment, but the brightness and heat are merely temporary. Character, on the other hand, is more like a bonfire. It's long lasting. It produces warmth and light. As it continues to burn, it gets hotter. This is a lesson that the Emerging Apostolic leaders must learn. This understanding can contribute enormously in averting the regular church splits 


\section{The temptation of Realpolitik and vox populi}

that are predominantly characteristic of the Charismatic churches in general. The voice of the masses is not a guarantee of sustainable church life development. The crowds witnessed the raising of Lazarus from the dead (Jn 11), and later shouted "Hosanna! Blessed is he who comes in the name of the Lord ..." (Jn 12), and later on, the very same crowds shouted: "Crucify him!" (Jn 19). This is vox populi. The glory of today for church leaders cannot be guaranteed tomorrow.

The apostolic leaders lead by popular vote. The popular vote is entrenched by the signs, wonders and miracles they perform. People follow the miracles, not the Lord, hence many of these followers fall with their leader when he falls. Faith is not based on miracles. A miracle is what you see. "We live by faith, not by sight" (2 Cor 5:7). Pannenberg (2001:224) reminds us that a "miracle as an event which cannot be explained in the stricter context of natural occurrence points to a higher power which is at work in the world, to the God of religion who is the Lord of nature." Many adherents of the Emerging Apostolic Churches claim faith in Christ while in the real sense they have faith in miracles or performers of those miracles. Is this not idolatry? The Emerging Apostolic leaders emphasise miracles by apostles, and these miracles are the drawing pins to mega meetings.

One of the reasons for the explosion of the Apostolic Churches especially in Africa is that their gospel is rooted in the wisdom of the kingdoms of this world. Their church structures are intimately tied to the economic, political, cultural, and military structures of the nations. Some apostolic leaders look to some secular governments as a way of securing some form of favour especially in the monetary sphere. The preaching on prosperity promises people deliverance from poverty. Some ecclesiastical leaders would like to demand a treatment of the State President. They are welcomed on a red carpet and fly business class wherever they go. They strive to develop friendships with political leaders. Their worship in indigenous styles draws many people into their gatherings. In some places the hierarchy is organised in the military systems. Their compromise on the gospel of separation but embracing numerous cultural norms makes people's voices to reign supreme. Realpolitik prevents people to look to God and to practise righteousness, justice, and fidelity. Vox populi encourages an optimistic and pragmatic way of life. The people selectively listen to the preaching of these apostolic leaders, and enjoy God's warm presence. It is therefore understandable why these leaders preach more on what God can do for you, at the expense of the cost of discipleship. My personal observation is that the apostolic leaders do not emphasise the seriousness of sin, and the life of holiness demanded by the New Testament teachings. This is explained by the gradual shift from 
revelation to vox populi. These apostles fix God's Word by subjective interpretation and traditions. The revelation of God cannot be restricted with myopic vision and tradition. This branch of evangelical faith reduces the eternal into temporal and spatial categories. In the contrary, this is taking the way of Realpolitik and vox populi.

The popular support in the Emerging Apostolic Churches represents the contemporary world system. To depend on the vox populi for credibility and vindication is a dangerous path of losing the prophetic role in the nation. The following highlights demonstrate the role of Realpolitik and vox populi in the polity of the new apostolic churches, and also how does this correspond with the sound theological teachings:

- The spiritual meaning becomes intertwined with cultural practices. The syncretistic way of doing church expedites popular recognition. In the theological sense, the ministers of the gospel operate solely from the framework of revelation. They are the guardians of the Word of God.

- The apostolic leaders select themes from the revelation of God that would comfort God's people. They believe in God's promises, but do not apply God's warnings and relating to seriousness of sin. Their kerygma is anthropocentric, not Christocentric. The theologically sound ministers of the gospel affirm the whole counsel of God. They oppose any human restriction on the freedom of God among His people. It is on this basis that Zimmerli (1977:100) declares, "Prophetic proclamation thus shatters and transforms tradition in order to announce the approach of the Living One."

- The Emerging Apostolic leaders foster illusions by advocating Realpolitik. They try to provide solutions for current problems - whether these problems are social, political, or economic. They are very much into socio-political structures than in ecclesiastical tasks. The true ministers of the gospel are the objects of ridicule, hatred, and plots. As van Gemeren (1990:64) asserts: "More often than not the prophet of the Lord was a lonely individual whose behaviour, clothing, and speech marked him as different from his contemporaries. He often did not enjoy simple human comforts as he suffered for the sake of Christ (Lk 20:9-15, Ac 7:52)."

- The Emerging Apostolic leaders live and work for a human ideal, dream, vision, or institution. They promote programmes and techniques 
and turn to routinisation of the Spirit. They garner to eternalize the present and to institutionalize the Spirit in space and time. Their meetings are full of dramatics and some homiletical gymnastics that sensationalise people (vox populi) and make them to sign pledges on demand without making a thorough mental application to their commitments. In the proper theological assessment, the ministers are expected to be the intermediaries between God and people. The prophetic calling of the church is both divine and social. It is divine because their mandate is from God and it is social because it is to people and among the people that it is exercised and directed. Realpolitik and vox populi play no role in the ecclesiastical programmes of communicating the divine will of God or the incarnating of God's love to His people.

- Although, this is not yet observable on a wider scale, the Emerging Apostolic leaders are on the path of becoming guardians of the status quo. Their vision of the kingdom, based mostly on the extra-biblical revelations, provide them with a myopic vision for new life found by faith in Christ. The "revelations" given or received by the "apostle" become sacrosanct and that the ministers start to guard them as holy ground not to be tampered with. The true ministers of God work by conviction that God is the sovereign King of the universe and $\mathrm{He}$ is in the business of establishing His kingdom by His Spirit. They passionately reject any human attempt of reconstructing or establishing the kingdom by Realpolitik (economic, social, power, etc structures).

- The Emerging Apostolic Churches teach human-centred morality. They embrace modern popular authors (vox populi) and spiritual disciplines (prayers, fastings, giving etc). True Christian ethics are both theocentric and eschatological. Theocentric ethics provide a system of interpreting God's word within the framework of who God is. An act is good only if done for the love of God rather for immediate reward and recognition. An act is good when it correspond with the vision of the transformed world of righteousness, justice, love, fidelity and peace.

- Many of the fivefold ministers gain popularity and power through a syncretistic, optimistic programme of Realpolitik. They are put into leadership by power, expected to excel and perform to the level of their apostolic mentors. Some, due to the lack of theological depth, come into the ministry with the baggage of the past. They perform according 
to expectation by the superiors. Richard Dobbins (Green 2005:139), captures this that "the growing numbers of independent churches put even fewer checks in place when credentialing people. Since independent churches are accountable to no other body of authority, the risk of pastoral abuse tends to be higher among them". The true ministers of the gospel suffer and agonise in prayers for the fulfilment of God's word (Heb 11:32).

Realpolitik and vox populi are a great danger to the spiritual health of the church. They put humanity at the centre of ecclesiastical life, instead of Christ and the Holy Spirit. The people in leadership (fivefold ministers) tend to lead their flocks ex cathedra. Regrettably, as a result of this elevated apostolic authority, the critical analysis of new apostolic ecclesiology has been affected by schisms, fragmentations, expressions of distrust, and misunderstandings. Disagreements arising from exegetical, theological, or philosophical differences have often been expressed with rigidity and lack of love, and certain interpretations have too often exalted apostolic authority as the test of ecclesiastical polity. The apostolic networks that are like ecumenical cooperations are excellent. The only danger may be that they are based on the needs of the day (Realpolitik), where one apostle would be vested with powers to rule. The spirit of competition may arise whereby the authenticity of apostolicity is based on the size of the network one oversees, or a number of congregations one leads.

\section{CONCLUSION}

\subsection{The fivefold ministry is untenable.}

The bases of Ephesians passages, especially 2:20 and 4:11 as authentic justification for modern apostles or fivefold ministry is hermeneutically and theologically questionable. Moriarty (1992:191) is in agreement:

It is a gross misinterpretation of Eph 2:20 to make apostles and prophets the key components for laying foundations in individual churches throughout history. Not only have this place sincere believers at the mercy of self-styled apostles and prophets, but it totally distorted the context in which Paul addresses the Ephesians on this issue. In verse 19 Paul uses a metaphor to explain that Jews and Gentiles who are in Christ are part of the same spiritual family: "You are fellow citizens with the saints, and are of God's household". The word household illustrates that Jews and Gentiles are more than fellow citizens, they are actually brothers and sisters 
in the family of God. Paul tells us the bases of this family for this new family's instruction and existence are its spiritual foundation 9apostles and prophets, who gave us the New Testament) and the cornerstone (Jesus Christ, who shapes and supports the entire foundation).

The foundation of the Christian church was laid by the first-century apostles and prophets. This church is supported, guided, and directed by its cornerstone, Jesus Christ. Its foundation that has been laid already cannot be tampered with. It cannot be changed or modified. The apostolic leaders seek to "lay" or "restore" a foundation which has never been moved. They are actually laying a faulty foundation on human desire for prosperity in philosophical and material bliss of this era.

The division of church history into epochs, as Bill Hamon (1999:123142) habitually does, is dangerous to the belief that God is sovereign and rules over the universe. His acts cannot be compartmentalised into decades or centuries. To claim that the 1990s were the era of the prophetic movement, while the 2000s were the era of apostolic revivals is historically flawed since the world as a whole is on eschatological journey towards the fulfilment of God's purposes for it. The revealed will of God (canon) is wholly available for the universe to assess its identity and destiny. To claim that our present age (New Apostolic Reformation), as Peter Wagner believes, is the age of apostles to awaken the church to something new that God is doing, is to separate God from history. God has always been at work, including during the Dark Ages.

The Emerging Apostolic Churches are faced with the challenges of globalisation whereby cultural norms are no more unique in giving one identity. What is needed is the central role of God's revealed will, and Christ's exaltation in all ecclesiastical endeavours. The unifying essentials in any articles of faith are crucial in bringing believers closer to each other (ecumenism). This has been replaced with apostolic networks. What about those outside these networks? Is there a possibility of synergy, cooperation, and communion at any level? Church history affirms that the true model of church government should foster unity and order, and preserve Biblical truth.

The methodology of governing the church through the fivefold ministry is impossible with the Emerging Apostolic Churches. These gifts of Christ were designed for a purpose of function, not position. The church is expected to be a functional church. Engrafting the fivefold ministers into the church governance structure is unsound as from the beginning the church was designed to be governed by the plurality of elders, not the fivefold ministers. In order to overcome the influence of Realpolitik and vox populi, leaders should 
accept a true model of government that should maintain a balance between the authority of the elders and the priesthood of all believers.

An overemphasis on the authority of the apostles can produce an overbearing and oppressive environment. The church is built by Christ and it is His authority that must be acknowledged. Every human invention in spiritual spheres cannot stand forever (Acts 5:38-39).

\subsection{Towards an alternative}

The hypothesis, are the Emerging Apostolic Churches ecclesiologically correct in centring the authority of governance in the fivefold ministers and the popular voices of the followers?, is attempted here from the evangelical point of view. In other words the highest appeal for verification is based on the theological understanding, hermeneutical principles, and ecclesiological analysis of this ecclesiastical phenomenon. The research on the new apostolic churches especially with regard to their ecclesiastical polity calls for:

- Return to the basics of hermeneutics where exegesis on the questioned passages of Ephesians 2:20 and 4:11 can be treated with fairness. The full study to be undertaken by the fivefold ministry promoters on these texts from all types of text criticism in order to catch the intended meaning of the fivefold ministry concept.

- The theological discourse is imperative for the fivefold ministry in a broader spectrum of ecclesiastical traditions. There is a need for theological scrutiny and depth on the subject. Continuing discussions and debates on the subject must be encouraged. The evangelical wing of Protestant faith to be encouraged to develop some synergy with the New Apostolic Churches and enter some understanding by contributing towards the development of this phenomenon.

- The need for "revelation" and established canon must be balanced in such a way that any extra-biblical revelation can be authentically convincing and to be accepted by the broader spectrum of Christendom.

- Ecclesiastical polity must be recognised as a full discipline to be studied at institutions of higher learning of theological disciplines. Though it is part of ecclesiological studies, polity needs special attention in this day and age where there is excessive proliferation that breeds confusion within the Christian tradition. 
- Realpolitik and vox populi pose a danger to ecclesiastical phenomenon, therefore ecclesiology students to be conscientised about it and be warned of its impending flaws in church life.

- The Emerging Apostolic Churches must realise that there is a need for emphasis on ecclesiology that presents a fundamental theological analysis and exposition of these churches, as a way of keeping them within the mainstream of the Protestant faith.

\section{Works consulted}

Barth, M 1974. Ephesians 4-6: A new translation with introduction and commentary. New York: Doubleday.

Broocks, R 2002. Every nation in our generation: Recovering the apostolic mandate. Lake Mary, FL: Creation House.

Bultmann, R 1965. Theologie des Neuen Testaments. Tübingen: Mohr Paul Siebeck. Cannistraci, D 1996. Apostles and the emerging apostolic movement: A Biblical look at apostleship and how God is using it to bless his church today. Ventura, CA: Renew Books.

Green, M D (Ed) 2005. Understanding the fivefold ministry. Lake Mary. FL: Charisma House.

Hamon, B 1999. Prophets and prophetic movement: God's prophetic move today. Shippenburg, PA: Destiny Image.

Hamon, B 2002. Apostles, prophets and the coming moves of God: God's end-time plans for his church and planet earth. Shippenburg, PA: Destiny Image.

Lloyd-Jones, M 1984. Christian unity: An exposition of Ephesians 4:1 to 16. Grand Rapids, MI: Baker Book House.

Long Jr, E L 2001. Patterns of polity: Varieties of church governance. Cleveland, $\mathrm{OH}$ : The Pilgrim Press.

Marshall, H I 1997. New Testament interpretation. Carlisle: Paternoster.

McQuilkin, J R 1983. Understanding and applying the Bible. Chicago, IL: Moody.

Moriarty, M G 1992. The new charismatics: A concerned voice responds to dangerous new trends. Grand Rapids, MI: Zondervan.

Myer, R 2006. Fivefold ministry made practical: How to release apostles, prophets, evangelists, pastors and teachers to equip today's church. Lititz, PA: House to House Publications.

Noll, R B 1993. Christian ministerial priesthood: A search for its beginnings in the primary documents of the apostolic fathers. San Francisco, CA: Catholic Scholars Press.

Pannenberg, W 2001. Systematic theology, Vol 1. Grand Rapids, MI: Eerdmans.

Paulk, E 1987. That the world may know. Atlanta, GA: K Dimension.

Payne, J L 2004. The five ministries: A New Testament church's study on the 5-fold ministry. Jackson, MS: Church House Publisher. 
Quebedeaux, R 1983. The new charismatics II: How a Christian renewal movement became part of the American religious mainstream. San Francisco, CA: Harper \& Row.

Robertson, A T 1931. Word pictures in the New Testament, Vol IV: The epistles of Paul. Nashville, TN: Broadman.

Stone, D 1999. Gifts from the ascended Christ: Restoring the place of the 5-fold ministry. Shippensburg, PA: Destiny Image.

Tenney, M C 1978. New Testament survey. Grand Rapids, MI: Eerdmans.

Trollope, A 2006. Autobiography of Anthony Trollope. Ferndale, MI: Indy Publishers.

Van Gemeren, W A 1990. Interpreting the prophetic word: An introduction to the prophetic literature of the Old Testament. Grand Rapids, MI: Zondervan.

Vine, W E 1952. An expository dictionary of New Testament words with their precise meanings for English readers. lowa Falls, IO: Riverside Book and Bible House.

Wagner, C P 1999. Churchquake: How the new apostolic reformation is shaking up the church as we know it. Ventura, CA: Regal Books.

Wagner, C P 2004. Changing church: How God is leading his church into the future. Ventura, CA: Regal Books.

Wagner, C P 2006. Apostles today. Ventura, CA: Regal Books.

Zimmerli, W 1977. Prophetic proclamation and reinterpretation, in Knight, D A (ed), Tradition and theology in the Old Testament. Philadelphia, PA: Fortress. 